Jure Gašparič

\title{
Writing the Political History of the Republic of Slovenia
}

\section{IZVLE ¿ EK \\ PISATI POLITIČNO ZGODOVINO REPUBLIKE SLOVENIJE}

Avtor $v$ prispevku obravnava problematiko raziskovanja in pisanja politične zgodovine Republike Slovenije po letu 1991. Po uvodni ugotovitvi, da ljudje od vsega začetka niso zaupali politikom in strankam, zastavi vprašanje, kako so ti ves čas ravnali, kako so se razvijale politične institucije, kako so se prilagajale svetu in času, ki se je v dvajsetih letih spremenil. Najprej predstavi številne dileme in metodološke posebnosti problematike (problem historične distance, smiselnost početja, neobvladljivost in specifičnost virov), nato pa oriše mogoče pristope in načine spopadanja z izzivom. $V$ drugem delu prispevka povzame ugotovitve lastnega raziskovanja tega obdobja (o polarizaciji, personalizaciji, medializaciji in informalizaciji politike), jih vpenja $v$ širši evropski okvir in poleg tega zariše še izziv za prihodnje raziskovanje.

Ključne besede: politična zgodovina, 1991-2016, Slovenija, politične stranke

\section{ABSTRACT}

The author focuses on the issue of researching and writing the political history of the Republic of Slovenia after its independence in 1991. After his introductory assessment that ever since the beginning people have not trusted politicians and political parties, he focuses on the question of how people have acted throughout this time, how the political institutions have been developing, and how they have been adapting to the world and the times which have changed radically in the last twenty five years. First the author presents numerous dilemmas and methodological peculiarities of the issue at hand (the problem of historical distance, the sensibility of the activity, the uncontrollable and specific sources), and then he proceeds to describe the possible approaches and methods of meeting this challenge. In the second part of the contribution the author sums up the findings resulting from his own research of this period (about the polarisation, personalisation, medialisation and informalisation of politics), placing them into the wider European context. Furthermore, he also outlines the challenges for future research.

Keywords: Political history, 1991-2016, Slovenia, political parties

* Senior Researcher, PhD, Institute of Contemporary History, Kongresni trg 1, 1000 - Ljubljana, Slovenia, jure.gasparic@inz.si 


\section{»A New Political Spectrum Is Being Created..."}

Attempting to write a paper about the development of the Slovenian politics of the last quarter of a century represents a special challenge and a kind of an adventure for historians. It is best illustrated by looking at the beginnings and the final stages of the period - namely, extreme points help historiography to correctly place and interpret the processes. Let us begin in 1993 and take a look at the young National Assembly (Slovenian Parliament). That autumn it was visited, in the middle of an intense budgetary discussion, by the Czech President Václav Havel, "Citizen Havel". The former dissident, dramatist and author of political essays addressed the Slovenian MPs with a short speech in accordance with his political thought about the "anti-political politics". ${ }^{1}$ The popular Havel symbolised the romantic, "velvet" image of the transition, which, however, was essentially quite a bit rougher than that in the Czech Republic as well as in Slovenia.

"One of the things we most definitely have in common is that we are both building a parliamentary democracy," Havel said.

"A new political spectrum is emerging, with new political subjects who are seeking their own identity and their place. These subjects are now searching for new avenues for cooperation, also with regard to the ways of representation. To put it simply, we are building a political system... However, many dangers lurk in this dramatic, interesting and exciting situation, and we should pay special attention to them. In my opinion, one of such dangers is that the parties in our territory could obtain an overrated role. It seems as if the state suddenly belonged to the political parties. As if the parties were not supposed to serve their country, but rather that the country should serve the parties... I wholeheartedly wish that your Parliament as well as ours were safe from these dangers, which have been preying on us in this difficult period." 2

As the most recent research of our Czech colleagues emphasises, in Havel's opinion the Czech Parliament was "not safe" from danger. As President, Havel constantly criticised it for being hesitant and slow. Havel's attitude was quite openly anti-parliamentary (which has until now been overlooked by those who have studied his work), and this stance of his was widely supported by the Czech people. ${ }^{3}$ However, Havel was not only supported by his own compatriots, but also by the citizens of Slovenia.

1 Jiří Suk, "Od nezmožnosti politiky k politice jako umění možného. Paradohní život občana Václava Havla v letech 1969-1992," in: Kapitoly z dějin české demokracie po roce 1989, ed. Adéla Gjuričová and Michal Kopeček (Praha and Litomyšl: Paseka, 2008), 16-51.

2 Dokumentacijsko-knjižnični oddelek Državnega zbora Republike Slovenije, Dobesedni zapis 13. seje I. mandata DZ z dne 9. 11. 1993 [Verbatim Record of 13th Session of the first Mandate]. Available at: Portal DZ, http://www.dz-rs.si.

3 Adéla Gjuričová, "Anti-politics and anti-parliamentarism. Václav Havel and the Czechoslovak parliament in the 1990s." Conference Paper (European Information and Research Network on Parliamentary History: Parlamentarismuskritik und Antiparlamentarismus in Europa. Berlin, 7 and 8 May 2015). 
Already in the time when the Slovenian political system was being formed - when there was a lot of optimism in the country - people did not trust the political institutions, parties and politicians. ${ }^{4}$ According to the former politician and Constitutional Court Judge Ciril Ribičič, people were supposedly convinced that the Parliament was a "gang of lazy spendthrifts". ${ }^{5}$ In the following years Slovenia became the absolute champion in almost all of the statistical categories used by Brussels to compare the countries of the European East. ${ }^{6}$ The slogan about the Story of Success spread, but the standpoint with regard to politics and political parties did not change. Quite the opposite: if we look at the end of "our period", at the year 2013, we can establish that this opinion of the people has only strengthened.

In 2013 the dissatisfaction resulting from the economic crisis kept getting increasingly profound and more and more obviously oriented against the political elites. ${ }^{7}$ The general disgruntlement, disappointment, resentment and mistrust due to - according to the people's conviction - inappropriate responses of the state gradually escalated into direct protests. The events started in the socially sensitive environment: in the city of Maribor, from where the spark of the "people's uprisings" also spread to other cities, including Ljubljana, where protesters would frequently gather in front of the Parliament en masse. Mottoes about the wrongfulness of the political system

4 Niko Toš, ed., Vrednote v prehodu VIII. Slovenija v srednje in vzhodnoevropskih primerjavah 19912011 (Ljubljana and Wien: Univerza v Ljubljani, Fakulteta za družbene vede, IDV-CJMMK and Edition Echoraum, 2014), 302. Jure Gašparič, "O samoumevnosti uvajanja parlamentarne demokracije v vzhodni Evropi po letu 1989.” Conference Paper (Regionalni vidiki tranzicije. Nova Gorica, 15 October 2015).

5 Ciril Ribičič, Siva tipka 074 (Ljubljana: Enotnost, 1995), 124.

6 At the tenth anniversary of the independent Slovenia, the Government Office for Communication presented the Slovenian achievements in the following manner: "In these past ten years Slovenia dismantled the old economy and set up a new one. It has a national shipbuilding industry and its own airline, a stock exchange, its World Trade Center and other institutions. With 892,000 people in employment, it boasts a per capita GDP of US\$ 9,150 and an inflation rate of 8.9 per cent. It introduced its own currency, the Slovene tolar, it has strong foreign exchange reserves, and a tax system that is increasingly in tune with that of Western Europe. The former socially-owned companies have been (almost) entirely privatised. Business activities are increasingly liberal, the exchange rate is favourable, the interest rate is high in real terms and fiscal policy envisages minimal budget deficits. Slovenia is rapidly becoming a transport hub, with the shortest route connecting France and Italy with Hungary (Milan-Ljubljana-Budapest), and the Balkans with Central Europe (Zagreb- Ljubljana-Munich). In the political arena it has become established as a partner and adviser on the margin of the turbulent Balkans. From its acceptance into the United Nations up to its membership of the Security Council, the Council of Europe, the Organisation for Security and Cooperation in Europe (OSCE), the World Trade Organisation (WTO), the International Monetary Fund (IMF) and other international institutions and also to becoming the most serious candidate country for membership of Nato and the European Union, it is mapping out the path of a recognised and established state in the modern world. It is an up-to-date, progressive democracy, while at the same time it has retained the unique image of a small nation that has not just survived millennia of foreign influence and rule, but has also entered into the new order as a winner." - Slovenia - 10 Years of Independence, 30 May 2016, http://www.slovenija2001. gov.si/10years/independence/.

7 The description of 2013 is based on my text about the sixth term of the National Assembly. See: Jure Gašparič, Slovenski parlament. Politično-zgodovinski pregled od začetka prvega do konca šestega mandata (1992-2014) - Elektronska izdaja 1.0 (Ljubljana: Inštitut za novejšo zgodovino, 2014). Available at: Zgodovina Slovenije - SIstory, http://www.sistory.si/SISTORY:ID:26950. 
as well as appeals for the introduction of direct democracy started appearing... Politics once again became similar to the oldest trade, and this was expressed by one of the protesters in a brutally direct, vulgar, but politically exceedingly meaningful banner: "A fuck or a refund!"

The beginning and the end of "our period" are thus, at the first glance, quite closely connected in terms of the issue at hand. The cause-and-effect relationship looks like this: a quarter of a century ago we started building a political system, but ever since the beginning we have been finding that it did not work very well and that it should not be trusted. Towards the end of our period we have shown this through protests. The interpretation is simple, but lacking a vital part: politics itself. What have the actions of the politicians been, how have the political institutions developed, and how have they adapted to the world and the times that have changed in the last twenty years? Obviously completely differently from what the people expected. Does this mean that politicians are irrational? Are the voters, who keep electing supposedly unsuitable politicians all the time, those who are irrational? How can we explain and describe politics in the modern world? Vaclav Havel once said: "We live in a postmodern world where everything is possible and nothing is certain." 8 In the opinion of many historians, the period after the Cold War is unclear and chaotic, "unlesbar", 9 and the same goes for politics. Despite many similarities with the political history of the older periods, delving into the more recent past is a true adventure, which at the very beginning poses a few important methodological questions, brings on challenges, reveals dilemmas, but at the same time already offers some answers in advance.

\section{About the Distinctiveness of the Topic and about the Dilemmas}

The first answer, which can often be noted in the media and in a part of the expert public, is that the research of the Slovenian politics after 1991 may be an interesting and relevant topic, but that nothing truly new can be written about it - at least not anything that has not already been written by those who wrote about it and deliberated on it as it was happening. ${ }^{10}$ This sort of history would therefore only make sense if the researcher stumbled upon reliable documents about one of the unknown or unexplained political scandals from the last quarter of the century.

Another preliminary answer, which is actually already a dilemma, concerns the

8 Quoted after: Andreas Rödder, 21.0. Eine kurze Geschichte der Gegenwart (München: C.H.Beck, 2016), 11.

9 Ibid.

10 When the biography of the former President Milan Kučan was published, a journalist of the Delo newspaper brought the attention to this issue as well when he asked the author the following: "I've mentioned to a few of my colleagues that I'm reading your book. Every one of them asked me the same question: 'Is there anything new in it?' What they meant was whether the book revealed anything to refute all of the previous interpretations..." - Matija Grah, "Vem za pričakovanja, da bom odkril skrivnosti murgelske kleti," Delo, 30 October 2015. 
question of the general sensibility of researching processes that have not yet come to their conclusion or we at least do not know that they have concluded. As it is, a quarter of a century of the Slovenian state is a period of a multi-layered transition, which is not yet complete in all of its aspects and surges (of course, it is questionable how to define the conclusions of processes). At the same time this period has been co-created by the elites that are still at least partly publicly active (and which, of course, interpret these processes in their own way). Hence it is supposedly too soon for historians to take a look at this period of time. Things which may seem very significant today and which the historians might focus on in their research could look completely insignificant in time (and vice versa). ${ }^{11}$ The history of the present, as George Kennan referred to it, is thus allegedly not truly possible.

The following dilemma, which is simultaneously a challenge, is related to the temporal component. What is a methodologically suitable manner at all in which historians could explore the recent politics and the phenomenon of the political? As it happens, the available materials are inexhaustible in all aspects, with regard to quantity as well as in terms of substantive and scientific breadth. Besides the enormous quantities of materials produced by the media - from newspapers to television, radio and internet sites - it is also possible to collect the oral sources from the participants of the political developments and make use of the vast quantity of the materials produced on a daily basis and published by the state or its institutions (reports on the work of the governments, handover files, studies, legislative materials, verbatim records of parliamentary sessions, etc.). On the one hand these materials are more diverse as, for example, the materials from the period of the first Yugoslav state (Kingdom of SHS/ Yugoslavia), but simultaneously also more extensive and more comprehensive (nonevaluated, unfiltered, preserved in their totality). Especially the audio-visual materials, which influence the world view of the today's generations most significantly, represent a special challenge and make the century-old historiographic rule Quod non est in actis non est in mundo quite problematic. ${ }^{12}$ Furthermore, a truly vast quantity of online and other digital contents is being produced today: tweets, Facebook posts, text messages... Quite a few resounding public stories have been triggered precisely by this sort of media, but nevertheless nobody archives these sorts of contents systematically.

At the same time the historians of the most contemporary period have numerous studies and analyses at their disposal as well as rough data produced by other sciences that focus on modernity. In order to research the period of the independent Republic of Slovenia it is critical to acquire the materials and analyses from the Social Science Data Archives ${ }^{13}$ - especially the surveys produced in the context of the Slo-

11 Rödder, 21.0. Eine kurze Geschichte der Gegenwart, 13.

12 To find out more about the challenges that the audiovisual media represent for the researchers of the present see: Thomas Lindenberger, "Vergangenes Hören und Sehen. Zeitgeschichte und ihre Herausforderung durch die audiovisuellen Medien," in: Zeithistorische Forschungen/Studies in Contemporary History, Online-Ausgabe, 1 (2004), H. 1, URL: http://www.zeithistorische-forschungen.de/12004/id=4586, Druckausgabe: 72-85.

13 See: O Arhivu družboslovnih podatkov, http://www.adp.fdv.uni-lj.si/o_arhivu/. 
venian Public Opinion research (these have been carried out continuously ever since the 1960s), studies of the political analysis centre, and other studies from the field of politology, sociology, and social sciences. Political economy researchers have the materials of economic institutes at their disposal, while almost all sciences contribute their viewpoint with regard to, for example, research policy.

The (un)manageable amount of materials on the one hand is closely connected with its research usefulness on the other hand. Naturally, all kinds of materials are useful for researchers. It is only a question of what the researchers focus on and how. However, the materials for the most recent period are largely permeated by the prejudice that they only represent the surface of the events - in accordance with the aforementioned answer or conviction that we already know everything about "our" period, and what we do not know has been concealed and will remain hidden. (Of course, I do not know according to what logic it will then be revealed to our descendants.)

\section{On the Approaches to the Topic and about the Dilemmas}

Quite a few challenges and dilemmas undoubtedly exist; we only have to ask ourselves how to deal with them. The first dilemma (or rather a preconception) for the researchers who claim that nothing new can be written about this period of time is actually the easiest to handle. We can look at it from a purely philosophical and theoretical as well as from the practical point of view. Namely, when we undertake any serious and methodologically sound research we cannot theoretically know what sort of interpretative conclusions we will reach. Any evaluation in advance can turn out as erroneous (for example, years ago I myself was convinced that from its very beginning King Alexander's Dictatorship in the Kingdom of Yugoslavia in 1930s kept generating new political problems instead of solving them, but later I kept discovering more and more that initially its image as well as its perception were completely different).

In the same vein the questions that we asked yesterday were perhaps completely different and non-essential in comparison with the issues that we are interested in today. Not long ago it was important which politician used to be a member of the League of Communists, while today we are already interested in other things. After all, this kind of questioning represents the essence and the general characteristic of historiography, which concerns all the historic periods. The present and the environment we live in always dictate the research questions. For example, in Germany the 2008 financial crisis resulted in a notably increased interest in the economic history in general. ${ }^{14}$ Simultaneously it is completely practical to claim that research in historiography, which does not lead to any new or original interpretations, is neither meaningless nor flawed. In a sense this is just another way of accumulating

14 Frank Bösch and Jürgen Danyel, "Die Zeitgeschichtsforschung und ihre Methoden," in: Zeitgeschichte - Konzepte und Methoden, eds. Frank Bösch and Jürgen Danyel (Göttingen: Vandenhoeck \& Ruprecht, 2012), 9-21, here 13. Rödder, 21.0. Eine kurze Geschichte der Gegenwart, 13. 
knowledge and bringing the attention to the topics and aspects of the historiographic science. However, in so far as research is integral and synthetically-oriented, it is especially meaningful and well-founded - after all, historiography is oriented towards writing complete interpretations.

Another dilemma - that the contemporary time is too young for historians, because historical distance is required for serious research - is justified up to a point. It is certainly simpler to research a remote and concluded process, unlike the today's seemingly chaotic times. Things are easier to interpret if we see them whole, including their beginning and end. However, the advantage represented by distance hides quite a dangerous inherent trap: the knowledge of the end. If we are familiar with the conclusion of a certain process, we are in danger of adapting the whole interpretation of the developments to this ending. We are in danger of looking for reasons in the actions of people, logical in view of the familiar ending (consequence), while forgetting that in history things happen even when nobody is planning them. ${ }^{15}$ The historians focusing on the present do not know the end, and therefore the relationship between the purpose and the supposed result cannot compromise their analyses. ${ }^{16}$

On the other hand, however, we should be aware that the history of the present can have rather direct effects on the formation of the self-image of the state and its citizens, as it studies a recent period and thus addresses the memories of the living or their direct descendants. The history of the present explains "our time", which is why people do care how it is described (this is not only an issue with the history of the present, but rather with all of contemporary history - perhaps in Slovenia this especially concerns the World War II historians). Historiography can contribute to the formation of a "suitable" self-image, just like it happened in Germany after World War II when the myth about the so-called "Erfolgsgeschichte" formed, as well as in Great Britain, where this period was for a long time characterised as the "postwar consensus". ${ }^{17}$ Addressing living contemporaries can therefore represent a specific trap for historians, but it is still much more manageable than what is probably the biggest research problem: the amount and variety of materials.

If only a few decades ago historians kept finding that the history of the most recent period was not possible since the thirty-year restriction on the access to ma-

15 The historian of ideas and concepts Quentin Skinner refers to this mistake as the myth of prolepsis. One of the researchers of the process of the dissolution of Yugoslavia Dejan Jović underlines the frequency of this mistake in the explanations of the end of the Socialist Federal Republic of Yugoslavia. - Dejan Jović, "Razlozi za raspad socijalističke Jugoslavije: kritička analiza postojećih interpretacija," Reč 62, No. 8 (June 2001), 91-157, here 142-52.

16 The German historian Andreas Wirsching, author of the book about the history of Europe in our time, also states that the advantage of researching the present lies in the "erzwungene Verzicht auf jegliche Teleologie." Namely, historians are not exposed to the danger of the teleological search for the purpose and goal of history. - Andreas Wirsching, Der Preis der Freiheit. Geschichte Europas in unserer Zeit (München: C.H.Beck, 2012), 14, 15.

17 The British historiography has characterised the post-war "consensus" as a myth. - Gabriele Metzler, "Zeitgeschichte: Begriff - Disziplin - Problem, Version: 1.0," in: Docupedia-Zeitgeschichte, 7 April 2014, https://docupedia.de/zg/Zeitgeschichte. 
terials was enforced, as a matter of principle, in all the archives, today the situation is quite the opposite. The ocean of sources is endless, and, moreover, these sources are different in many aspects from, for example, the sources for studying the history of the First Yugoslavia. In both cases we can outline the developments in politics on the basis of newspaper articles; in both cases we can resort to documents that have been preserved (it seems interesting that historians do not have either the complete archives of the pre-war political parties nor the archives of the today's parties at their disposal); ${ }^{18}$ and in both cases we can also make use of political memoirs ${ }^{19}$ and verbatim records of parliamentary sessions. However, here the similarities end. Of course, it is questionable to what a degree the dissimilarity of sources hinders the political historians in their research. In principle this should not represent an obstacle, but it is certainly a kind of a challenge. First we have to be aware that every period has its own sources with their own particular characteristics. The materials about the Theresian reforms of the $18^{\text {th }}$ century are certainly different from those about the history of the Communist Party after 1945, and these again differ from the materials about the contemporaneous politics. Today the world is different and individuals operate and work in accordance with other guidelines. In the past a large amount of meeting-minutes was available, and the archives also frequently contained personal notes, letters, and so on. Today these materials are virtually non-existent and unavailable for historians; but we do have television, the internet, living participants of the events, etc. These sources appear less reliable than archival documents, at least at the first glance, even though they can be much more telling. This is especially true of the oral sources - witnesses, once upon a time seen as the "enemies of historians", ${ }^{20}$ can also enrich the available historiographic material considerably, if only we gather and methodologically process their testimonies in a suitable manner. ${ }^{21}$

All of the sources of our time - the classic ones, known already from the previous periods (especially newspapers, verbatim records of parliamentary sessions and legislative materials), as well as the newer (digital) sources - can be thoroughly analysed and evaluated only if we apply the following two approaches: interdisciplinarity and

18 Currently only the materials of three parties - the socialists, the Greens and the Liberal Democracy of Slovenia - are in the Archives of the Republic of Slovenia. Of these the LDS was the most influential and has, to date, taken part in the various governments the longest (SI AS 366, Socialistična stranka Slovenije (1990-1993), SI AS 2117, Zeleni Slovenije (1990-1993), SI AS 2111 Liberalna demokracija Slovenije (1976-2011)).

19 Quite a few memorial records by the politicians of our period exist, but they focus either on the time of the Slovenian emancipation or represent merely a collection of thoughts and notes about a certain period of time (which may also be very interesting and useful in terms of research). However, only a few of these texts are systematic and chronologically ordered, focusing on concrete political developments. See for example Ivo Hvalica, Zadnja replika (Ljubljana: Promag, 2002). Ciril Ribičič, Siva tipka 074 (Ljubljana: Enotnost, 1995). Miran Potrč, Klic k razumu. Spomini (Ljubljana: Modrijan, 2014).

20 The collocation was coined by Wolfgang Kraushaar when he problematised the German historiography about the 1968 movement. - Metzler, "Zeitgeschichte: Begriff - Disziplin - Problem."

21 See: Zdenko Čepič et al., Prikrita modra mreža. Organi za notranje zadeve Republike Slovenije v projektu MSNZ leta 1990 (Ljubljana: Inštitut za novejšo zgodovino and Zveza policijskih veteranskih društev Sever, 2010). 
the tools provided by the today's digital humanities. The latter enables us to focus on new research questions and process extraordinary amounts of materials (we can easily analyse the characteristics of the parliamentary discussions in the period of fifty years, which used to be physically impossible before), while interdisciplinarity ensures a more thorough and focused approach. As it is, research into modernity focuses more and more on the topics and problems, while the distinctions between the individual disciplines are being blurred. ${ }^{22}$ Thus nowadays politologists, lawyers, linguists, anthropologists and historians cooperate (or have done so) in practice. ${ }^{23}$

Finally, what about the prejudice that the available materials do not reveal all the secrets? The situation is similar as it used to be. Also in the Habsburg Monarchy and in the First Yugoslavia everyone was convinced that the political decisions were adopted behind the doors of smoky cabinets and coffee houses, which is what the notes (sometimes different from one another) of various political actors attest to.

In principle the digression about the materials of our period could be much longer than what I have just written, and all the concrete problems that the researchers may stumble upon cannot be predicted at all. Therefore I would just like to underline one more issue that I have faced myself, closely connected with the sheer amount of the materials and density of the political developments. In so far as a researcher's ambition is to comprehensively describe a certain political period at least to a certain degree, the massive amount of the materials at the initial stages dictates a descriptive approach. Thus the wish to control and encompass everything in itself impedes any methodological creativity. ${ }^{24}$ However, if researchers only have a limited amount of materials at their disposal, they are forced to resort to different approaches and can at the same time be more daring in the thesis they propose.

\section{Topic Presentation}

Regardless of all the dilemmas and methodological challenges I will now take the first step into the adventure and give a short description of the political history of the independent Slovenia, on the basis of which it will be possible to ask new questions and open new research dilemmas. In the book about the history of the Slovenian Parliament I have outlined the basic sequence of events with the main chapters of the post-independence development. Here I will sum up its main points. ${ }^{25}$ It seems that the events in the last twenty years can be most logically broken down by the parliamentary terms of office. ${ }^{26}$

22 Metzler, "Zeitgeschichte: Begriff - Disziplin - Problem."

23 See Conference Program: Parliaments and Methodology. Anthropological, Discourse-Oriented and Digital Approaches to Parliamentary History. Helsinki and Jyväskylä, Finland 12-14 June 2014, 1 June 2016, https://www.jyu.fi/en/congress/parliaments-and-methodology/program/EuParl_Programme.pdf.

24 Bösch and Danyel, "Die Zeitgeschichtsforschung und ihre Methoden," 9, 10.

25 Jure Gašparič, Državni zbor 1992-2012. O slovenskem parlamentarizmu (Ljubljana: Inštitut za novejšo zgodovino, 2012).

26 This may seem self-evident, but the questions of the periodisation and (non)linearity of the 


\section{In the shadow of the transition (the 1992-1996 term)}

At the first National Assembly elections in 1992, party-based democracy was still in its infancy and the political arena, in which the parties had not yet introduced clear and coherent programmes, was as a result somewhat vague and unclear. In the elections, each party had their own electoral tactics, and the campaign was not lacking low blows and brutal confrontations. Numerous transitional characteristics could be seen in the campaign. It was something new and it did not only shake up political life, but society in general, it drew the attention of many citizens and included many scandalous stories, happily gloated over by journalists and citizens alike. In those days, as well as later, party leaders found themselves being exposed. At the same time as parliamentary elections, presidential elections were also held; the first President of the Republic of Slovenia was Milan Kučan. ${ }^{27}$

The National Assembly's first line-up was rather fragmented, eight parties gained seats and the majority of votes went to LDS (Liberal Democratic Party), with the remaining parties far behind. The political leader Janez Drnovšek formed a diverse coalition dubbed the "small political miracle" - it was composed of LDS, Christian Democrats, United List (Združena lista) and SDSS (Social Democratic Party of Slovenia). Once the relationships between coalition and opposition were established, the Parliament and the Government began addressing its vast agenda. First and foremost, the agenda dealt with urgent legislative activities, as the former federal legislation had to be replaced on the one hand, and fundamental documents of numerous state subsystems had to be adopted on the other - from education, judiciary administration, tax system, ownership transformation, and the formation of a new economic system, to national security, political parties, and corruption. In addition to fundamental legislative activities, the common thread of the first National Assembly term was economic issues. Throughout the term, Drnovšek's coalition gradually dissolved, with only the LDS and SKD (Slovenian Christian Democrats) remaining in the end. ${ }^{28}$

\section{The weakness of the great coalition (the 1996-2000 term)}

After elections, the second convocation of the National Assembly found itself in a stalemate position. The parties of the so-called transition right wing (new parties, formed in the late 1980s and early 1990s) aggregately received 45 votes and all others (mainly parties, based on former socialist organisations), including the two members representing minorities and supporting the actual Prime Minister Drnovšek

development are not always easy. The Czech colleagues have decided for a similar division as well. See: Jan Wintr, Česká parlamentní kultura (Praha: Auditorium, 2010).

27 Milan Kučan is the first among the most visible politicians of our time about whom a serious historiographical political biography has been written. See: Božo Repe, Milan Kučan, prvi predsednik (Ljubljana: Modrijan, 2015).

28 Gašparič, Državni zbor 1992-2012, 53-70. 
(the president of LDS, the party that was the relative winner in the elections), also received 45 votes. The Parliament, a reflection of the society, found itself in a predicament, divided equally in half ... The constitutive session dragged on and on and opposing views were in evidence at each parliamentary step. However, the politicians finally managed to reach an agreement resulting in a large coalition between the largest parties, LDS and SLS (Slovene People's Party), joined by DeSUS.

The coalition that was finally formed after a difficult few months was very diverse despite the small number of partners because LDS and SLS represented a combination of two conceptually and socially completely different parties. In practice, during the second term, this thesis was confirmed by parliamentary practice to a large extent. Conditions and realities in the National Assembly were often confusing; it seemed that SLS was more of an opposition party than a coalition party. Furthermore, the opposition failed to attack and control the government in a coordinated manner because it was also divided itself on an ideological level. SDS and SKD were closer to SLS and ZLSD was closer to Liberal Democratic Party. The dissolution of the coalition often seemed inevitable. In November 1997, presidential elections for a five-year term were once again held. Despite some reservations, Milan Kučan ran again and won the election in a landslide (for the last time).

Despite all of its crises (which were quite frequent, especially those related to personnel), the shaky coalition between LDS and SLS managed to keep going until the eve of the end of its term. In the spring of 2000, only six months before elections, the coalition-opposition relationships in the Parliaments were blown apart. After many difficult meetings with ups and downs, the related parties, SLS and SKD, finally managed to agree on merging into one party that would not be a part of the coalition. The fall of the "falling" government was impending. Drnovšek did not wait for things to develop further; he was a step ahead of his partners and proposed the replacement of SLS ministers with new ones. A vote of confidence was connected with the replacement of ministers, but it was not passed. After merging, SLS and SKD became the largest party in Parliament and shortly after the demise of Drnovšek it proposed Andrej Bajuk as the new Prime Minister. However, the new parliamentary coalition was not destined to last for long, as the second term was about to end in less than six months. Also, the coalition itself experienced a severe political crisis after only a month. ${ }^{29}$

\section{Leftist domination (the 2000-2004 term)}

On Sunday, 15 October 2000, the third National Assembly elections took place in Slovenia. Once again, there was an election campaign and many appearances took place, mainly by well-known parties and faces ... The elections that occurred at the turn of the decade, century, and millennium did not represent a major milestone themselves, but they symbolically marked the entry into a new era. The first decade

29 Ibid., 71-91. 
after the fall of the Berlin Wall, named the "Time of Freedom" by the British historian Timothy Garton Ash, was coming to an end and a new "nameless decade" was beginning; this was an elusive period without clear features. ${ }^{30} \mathrm{~A}$ year earlier a common European currency was introduced and NATO expanded into its first three eastern European countries, thus giving special emphasis on integration processes. The following year, on 5 October 2000, only ten days prior to elections in Slovenia, the last Yugoslav tyrant was overthrown - the Serbian leader Slobodan Milošević. All of this may seem like some historical censorship of an epoch. Slovenia was a part of these global currents and during its third National Assembly term also joined the European Union and NATO, symbolically (maybe even in an illusory manner) concluding the transition process in the country. On top of everything, the third term was also the last term led by Drnovšek's great LDS, the strongest party after 1992. The election results on 15 October 2000 were its swansong. LDS received $36.21 \%$ votes, assuring it 34 seats in the Parliament. It formed a coalition with ZLSD, SLS and DeSUS.

To a large extent, the third term and the forms of parliamentary work were characterised by the weakness of the opposition, the core of which were SDS (former SDSS, renamed in Slovenian Democratic Party) and NSi (new party named New Slovenia). The coalition was soon nicknamed "voting steamroller" and in such conditions the opposition had to remain firm. During the term, in 2002, the government had a new Prime Minister (Tone Rop) following Janez Drnovšek's election to President of the Republic. ${ }^{31}$

\section{Rightist domination (the 2004-2008 term)}

On the one hand, the fourth National Assembly elections, which were called by the President of the Republic to take place on 3 October 2004, gave the impression of an entirely every-day democratic routine with a standard election campaign, and yet on the other they continued to be stuck in established ideological and political patterns. The "cultural fight" between the "left wing" and the "right wing" continued, though its intensity decreased. The election results were not entirely unexpected, but they marked a major ideological turning point. The great LDS lost for the first time after 1992. On that Sunday, the winner was SDS with its leader Janez Janša, who gradually became the flag bearer of the opposition after 1996. Janša then also formed a coalition and became the Prime Minister. If the distinct supremacy of the coalition and the weakness of the opposition marked the third term, one could conclude that the fourth term would be completely different in this regard. The coalition was smaller, more diverse, and two hard-bitten parties in the opposition preyed on it, not allowing the Government to even have the traditional 100 days of peace. Different

30 Timothy Garton Ash, Jahrhundertwende. Weltpolitische Betrachtungen 2000-2010 (München: Carl Hanser Verlag München, 2010), 17, 18.

31 Gašparič, Državni zbor 1992-2012, 92-107. 
conditions and practices in Parliament were to be expected. However, no significant changes occurred and the initial (unrealistic) expectations crumpled. At the beginning, the stability and support of the coalition and the Government were high (also in public opinion), but on the hand, the opposition succumbed to internal searching and splits. In particular, LDS seemed to have been experiencing a crisis. Therefore, the fourth term was similar to the third term, only a few roles changed. European topics were the undeniable cohesive element of politics and numerous other topics were divisive along the traditional left-right axis. During this time, in 2007, new presidential elections were held, but Janez Drnovšek did not run again due to illness. The winner was Danilo Türk. 32

\section{In the shadow of the crisis (the 2008-2011 term)}

On the eve of the fifth National Assembly elections in September 2008, the Slovene political arena seemed quite clear and predictable. The common thread of all parties was "welfare", but the plans in their programmes to achieve welfare were increasingly less specific and noticeably increasingly more alike. Contrary to expectations, the relative victory went to the party SD (Social Democrats) formerly known as ZLSD whose leader, Borut Pahor, became the Prime Minister.

On the eve of the elections, it was already clear that a debt and financial crisis is spreading around the world and that it might grow into a wider economic crisis affecting Slovenia as well. Pahor's team gave the impression that it was aware of the situation, but in the following few months, it acted slowly and indecisively as per the Prime Minister's consensual approach. The first bundle of anti-crisis measures reached the Parliament at the end of the year. It was adopted by Members of Parliament on their last sitting in 2008, thus symbolically foreshadowing the main focus of the fifth term - overcoming the crisis which finally grew from a financial crisis into a political one.

Throughout the term, there was division on all important topics (or at least those that were stressed as such). When the Government finally managed to agree on a solution for the border issue with the neighbouring Croatia, which must undoubtedly be counted as one of its major successes, it immediately encountered firm objections from the opposition and a portion of prominent intellectuals (however, a large portion of intellectuals in the public eye supported the agreement). During the third year of the term, the trust in the Government and the Parliament was still low and dissatisfaction grew. The political arena remained implacable and the coalition was increasingly giving the impression that it was blocked from the outside and from within and that it did not have any real "exit" ideas. The path into a political crisis was thus set. The coalition gradually dissolved, ultimately consisting only of SD and LDS.

The fifth term ended by a vote of no confidence given to the Government and,

32 Ibid., 108-23. 
with no new candidate for a Prime Minister, the President dissolved the National Assembly on 21 October 2011. For the first time in (nearly) twenty years of the Slovenian Parliament, early elections were to take place, planned for 4 December 2011. The trust in a significant portion of parliamentary parties was shaken and a significant restructuring of the political arena was to be expected. ${ }^{33}$

\section{The time of disappointment and weariness (the 2011-2014 term)}

Between the President's announcement that he would dissolve the National Assembly and the elections, there was not much time. In such circumstances, it was not surprising that the campaign lacked truly innovative approaches, convincing and insightful solutions and compelling addresses to the voters. The elections were quite peaceful (but not without scandals) and, for the first time in twenty years, divisive ideological topics were more evidently pushed into the background. In early October, the political atmosphere was still predictable. However, shortly afterwards, the political arena began to change drastically as new political faces and new parties appeared one after another. Less than two months prior to elections, two new parties with an extremely high rating appeared, as they climbed to the top of election polls. The first one was founded by the Mayor or Ljubljana, Zoran Jankovič (PS -Pozitivna Slovenija - Positive Slovenia), and the second by the former minister Gregor Virant (Državljanska lista Gregorja Viranta - Gregor Virant's Civic List).

If the campaign warned of major political shifts in Slovenia, the election results on Sunday, 4 December 2011, only confirmed them. The election was won by Jankovičs PS, but its president - again, for the first time in twenty years - did not become Prime Minister. The coalition was formed by Janez Janša, the leader of SDS, which received the second highest number of votes. The Parliament and the Government began fervently working and dealing with the crisis and the fiscal consolidation of the country.

The dissatisfaction of people due to the economic crisis gradually increased in the second half of 2012 and was directed specifically at political elites. Numerous "people's uprisings" erupted. In such circumstances, the coalition collapsed and in March 2013 a new Slovenian Government was formed under the leadership of Alenka Bratušek of PS (first woman Prime Minister). After the new Government was elected, the political storm calmed down for one year despite numerous troubles in the Cabinet and unsuccessful staff choices, until Bratušek resigned. This automatically ended the term for the entire Cabinet. No one proposed a new political figure to form a government and the new President, Borut Pahor, elected in 2012, dissolved the Parliament on 2 June and called for elections to be held on 13 July 2014 (with harsh criticism due to the summer holiday period). ${ }^{34}$

33 Ibid., 124-43.

34 Gašparič, Slovenski parlament, 81-96. 


\section{The 2014- term}

It was expected that the elections would, as in 2011, significantly change the political and personnel structure of the Parliament. There were several reasons for this. Following the demise of Janša's Government, the momentum of people's uprisings began to decline. However, the dissatisfaction with politics and political elites remained and the results of public opinion polls continued to be unforgiving. Therefore, a few uprising groups, such as the All-Slovene People's Uprising, decided to use the potential of the uprisings to actively enter into politics. In December 2013, the party Solidarnost (Solidarity) was formed. The next year, on 1 March 2014, the party United Left (Združena levica) was formed following the example of the then still attractive and convincing Syriza in Greece. Just prior to the elections, additional three parties entered the political arena: the party Verjamem (I Believe) led by Igor Šoltes, Alliance of Alenka Bratušek, and the Party of Miro Cerar. The latter (later renamed into the Modern Centre Party) ultimately won with the largest percentage of votes after 1992 and subsequently formed the current Slovenian Government together with SD and DeSUS. ${ }^{35}$

The political situation has calmed down and it seems that politics has retreated to the background somewhat...

\section{Findings and Challenges}

What conclusions can we draw on the basis of this short insight in the political history of the last quarter of a century? Firstly, the introductory finding that out period is very dynamic, riddled with events and "unreadable" can certainly be confirmed. Despite the relative political stability of the Slovenian governments (in comparison with the Czech Republic, for example), the party space has been unstable and ever changing, in a continuous state of restructuring. Its most notable constant was the polarisation - the division of the political actors into the Slovenian left and right. Furthermore, certain characteristics already noted in the broader European space can also be ascribed to the Slovenian development: the personalisation of politics, medialisation, and informalisation. ${ }^{36}$

Let us first look at the phenomenon of the left-right polarisation. Where does it originate from and what is its perception based on? At list partly the dividing line was (and still is) the attitude of the political parties to the past, especially to World War II and the post-war socialist period. In this regard certain parties see Yugoslavia and its society in an exceedingly binary manner. Their interpretative pattern is totalitarianhistorical, reducing the past merely to good and evil. ${ }^{37}$ The adherents of this pattern

35 Ibid.

36 Wirsching, Der Preis der Freiheit, 308-18.

37 See: Michal Pullmann, Konec experimentu. Prestavba a pád komunismu v Československu (Praha: Scriptorium, 2011), 15, 16. 
only look at this state in order to find arguments for and against their views. According to them an "evil" regime reigned in Yugoslavia, which was an "artificial creation" that repressed the good of the society. Some of them may acknowledge, though, that Yugoslavia also had some advantages. Such a generalised claim is disputable already in the very analytical sense, since it presupposes that people were nothing but indoctrinated masses, incapable of taking care of themselves and simply persisting quietly in the Yugoslav framework. However, as soon as these masses became capable of thought, they immediately wanted to break free of the Titoist chains and seek safe haven in their own democratic national states. This pattern is clearly understandable and politically useful, but it overlooks the actual disposition of the people.

The attitude towards the past can be associated with the issues of continuity and discontinuity in the historical development. Despite the various convictions of individual political parties, in the development after 1990 and 1991 we can notice many elements of continuity from the previous period as well as radical turning points and transformations, which is characteristic for the whole of the eastern Central Europe. ${ }^{38}$ We can also discern that the parties with their emphasised interest in history and their opinions about it frequently introduce additional confusion into the political space or contribute to the mythisation of the past. There are ample examples: for instance, in the last twenty-five years two parties from opposing sides appealed to the heritage of the social democratic party from Austria, established in 1896. The president of the Slovenian People's Party stated that he was extremely proud to be the successor of Anton Korošec, the most eminent Slovenian politician in the First Yugoslavia, even though the today's Slovenian People's Party has nothing to do with Korošec (except fictitiously). ${ }^{39}$ Later another party referred to Korošec's party as well...

The personalisation of politics is another characteristic of the Slovenian politics as well as of the European politics of our time. This may be nothing new, as we have known many examples of outstanding political personae in the post-war Europe (e.g. Charles de Gaulle, Willy Brandt). However, these were always personifications of concrete contents and standpoints. On the other hand, after 1990 we find that in Europe political personalities per se have come to the forefront, frequently without any contents (they have even been known to form their parties in an ad hoc manner). ${ }^{40}$ Slovenia is no exception in this regard. It seems that few parties are resilient enough to survive the replacement of their main leaders, whom all the spotlights are aimed at, without significant turmoil. ${ }^{41}$ The latter phenomenon is

38 Gašparič, "O samoumevnosti uvajanja parlamentarne demokracije v vzhodni Evropi."

39 Cf. Mateja Ratej, "Začetki politične pluralizacije v pojugoslovanski Sloveniji. Vprašanje političnega nasledstva Koroščeve SLS,” Zgodovinski časopis 67, No. 3-4 (2013), 472-92.

40 Wirsching, Der Preis der Freiheit, 313-15.

41 On the other hand, the pre-election events in the neighbouring Croatia in the summer of 2016 attest to the fact that the replacement of an unpopular president of the party with a more likeable leader can swiftly restore the trust of the voters in the party. As it happened, after the fall of the Most-HDZ coalition government in June 2016 it seemed that the HDZ and its President Tomislav Karamarko 
certainly closely connected with the medialisation of politics, which is also a wider all-European characteristic. ${ }^{42}$ While jumbo posters were a great novelty of the campaigns back in 1992, the political actions of today are taking place on a variety of media platforms. The Parliament may still be the central arena for political debates, but other formats represent an increasingly serious competition. Furthermore it seems that the Parliament in its essence is mostly and merely the following: the arena for debates and not the space where politics is being formed. In the people's opinion, serious political decisions are reached far away from the public gaze, which means that politics is informalised. This is also nothing new: we have already underlined that even in the old Yugoslavia and old Austria people were frequently convinced that politics is being made behind closed doors, often in the absence of the Parliament (the only difference is that once upon a time the cabinets and coffee houses were filled with smoke, which is probably a thing of the past). However, back then the frustrated Members of Parliament finally gave vent to their irritation by engaging in severe obstructions. In our period, however, deputies are simply overburdened with their functions in the working bodies and other activities, which may consequently diminish the importance of the Parliament. ${ }^{43}$

In light of these findings it seems that the connection between the introductory Havel's warning and the large-scale anti-political demonstrations is more understandable. Nobody (or almost nobody) wanted to undermine the trust in the parliamentary democracy intentionally. That simply happened due to the aforementioned characteristics of politics. There is no cause-and-effect relationship; and this, on the other hand, gives rise to other questions, partially focused on the future. One of the first questions is whether we have arrived to the end of the big and deeply-rooted parties with their traditional electoral bases. This does not seem impossible. In 2005 a large-scale public opinion research was carried out among the voters in the Western European countries, who responded that political parties were necessary, but also rejected the thesis that the existent parties were truly concerned with the welfare of the people. ${ }^{44}$ So what is the alternative, then? In parliamentary democracy the alternative can only be another political party, but in the future such a party will have to be very different from those established a quarter of a century ago. The detailed exploration of party-political dynamics is thus certainly one of the research challenges - not only external dynamics, but possibly also the dynamics within the parties themselves, in so far as the researchers are enabled to analyse that. Shedding some light on the party dynamics will finally allow us to gain a better insight in the decision-making process. The aforementioned collaboration of anthropologists, linguists, politologists and historians should be ensured, since the issue is multi-layered and the answers are not necessarily rational.

would certainly be defeated at the elections. However, the sentiment of the electoral body changed in just a few months - when the party was taken over by Andrej Plenković.

42 Wirsching, Der Preis der Freiheit, 312.

43 Ibid., 311.

44 Ibid., 347. 
As it is, politics is not a game of chess, as the German historian Gerhard A. Ritter wrote wittily. ${ }^{45}$ Nobody is forced to make their move once the opponent has made one. Politicians are frequently lost. Time and again they do not do anything, their actions are often irrational, and concrete results are frequently unrelated to their actions. However, when the moment is right, some of them know how to exploit it and are capable of doing it (after which they, of course, present their actions as a result of a strategic consideration). ${ }^{46}$ The factor of time - the context - thus remains an essential element of the analysis, and without it we cannot truly understand politics.

\section{Sources and Literature}

- Ash, Timothy Garton. Jahrhundertwende. Weltpolitische Betrachtungen 2000-2010. München: Carl Hanser Verlag München, 2010.

- Bösch, Frank and Jürgen Danyel. "Die Zeitgeschichtsforschung und ihre Methoden." In: Zeitgeschichte - Konzepte und Methoden, eds. Frank Bösch and Jürgen Danyel, 9-21. Göttingen: Vandenhoeck \& Ruprecht, 2012.

- Čepič, Zdenko, Filip Čuček, Jure Gašparič, Damijan Guštin, Božo Repe and Uroš Svete. Prikrita modra mreža. Organi za notranje zadeve Republike Slovenije v projektu MSNZ leta 1990. Ljubljana: Inštitut za novejšo zgodovino and Zveza policijskih veteranskih društev Sever, 2010.

- Dokumentacijsko-knjižnični oddelek Državnega zbora Republike Slovenije, Dobesedni zapis 13. seje I. mandata DZ z dne 9. 11. 1993 [Verbatim Record of $13^{\text {th }}$ Session of the $1^{\text {st }}$ Mandate]. Available at: Portal DZ. http://www.dz-rs.si.

- Fischer, Joschka. Rdeče-zelena leta. Prelomni dogodki od vojne na Kosovu do 11. septembra. Ljubljana: Didakta, 2011 (Orig. Die rot-grünen Jahre. Deutsche Außenpolitik - vom Kosovo bis zum 11. September).

- Gašparič, Jure. "O samoumevnosti uvajanja parlamentarne demokracije v vzhodni Evropi po letu 1989." Conference Paper (Regionalni vidiki tranzicije. Nova Gorica, 15 October 2015).

- Gašparič, Jure. Državni zbor 1992-2012. O slovenskem parlamentarizmu. Ljubljana: Inštitut za novejšo zgodovino, 2012.

- Gašparič, Jure. Slovenski parlament. Politično-zgodovinski pregled od začetka prvega do konca šestega mandata (1992-2014) - Elektronska izdaja 1.0. Ljubljana: Inštitut za novejšo zgodovino, 2014. Available at: Zgodovina Slovenije - SIstory. http://www.sistory.si/SISTORY:ID:26950.

- Gjuričová, Adéla. "Anti-politics and anti-parliamentarism. Václav Havel and the Czechoslovak parliament in the 1990s." Conference Paper (European Information and Research Network on Parliamentary History: Parlamentarismuskritik und Antiparlamentarismus in Europa. Berlin, 7. and 8 May 2015).

- Grah, Matija. "Vem za pričakovanja, da bom odkril skrivnosti murgelske kleti.” Delo, 30. October 2015.

45 Gerhard A. Ritter, Der Umbruch von 1989/91 und die Geschichtswissenschaft. Bayerische Akademie der Wissenschaften. Philosophisch-historische Klasse. Sitzungsberichte. Jahrgang 1995, Heft 5 (München, 1995), 23.

46 The former German Vice-Chancellor and Minister of Foreign Affairs Joschka Fischer admitted this freely in his memoirs, as he wrote that without the financial scandal of the CDU party the red-green coalition, created in 1998, would never have existed: "Luck and chance are essential for politics, like the air we breathe. What is later shown as a brilliant plan or a well thought-out strategy, or what the actors later declare as such, is often a result of chance or simply luck, not so much of the alleged genius of the people involved." - Joschka Fischer, Rdeče-zelena leta. Prelomni dogodki od vojne na Kosovu do 11. Septembra (Ljubljana: Didakta, 2011), 271. 
- Hvalica, Ivo. Zadnja replika. Ljubljana: Promag, 2002.

- Jović, Dejan. "Razlozi za raspad socijalističke Jugoslavije: kritička analiza postojećih interpretacija." Reč 62, No. 8 (June 2011): 91-157.

- Lindenberger, Thomas. "Vergangenes Hören und Sehen. Zeitgeschichte und ihre Herausforderung durch die audiovisuellen Medien." In: Zeithistorische Forschungen/Studies in Contemporary History, Online-Ausgabe, 1 (2004), H. 1. URL: http://www.zeithistorische-forschungen.de/1-2004/ id $=4586$, Druckausgabe: $72-85$.

- Metzler, Gabriele. “Zeitgeschichte: Begriff - Disziplin - Problem, Version: 1.0.” In: DocupediaZeitgeschichte, 7. April 2014. https://docupedia.de/zg/Zeitgeschichte.

- O Arhivu družboslovnih podatkov. http://www.adp.fdv.uni-lj.si/o_arhivu/.

- Parliaments and Methodology: Anthropological, Discourse-Oriented and Digital Approaches to Parliamentary History. Helsinki and Jyväskylä, Finland 12-14 June 2014. https://www.jyu.fi/en/congress/parliaments-and-methodology/program/EuParl_Programme.pdf.

- Potrč, Miran. Klic k razumu. Spomini. Ljubljana: Modrijan, 2014.

- Pullmann, Michal. Konec experimentu. Přestavba a pád komunismu v Československu. Praha: Scriptorium, 2011.

- Ratej, Mateja. "Začetki politične pluralizacije v pojugoslovanski Sloveniji. Vprašanje političnega nasledstva Koroščeve SLS.” Zgodovinski časopis 67, No. 3-4 (2013): 472-92.

- Repe, Božo. Milan Kučan, prvi predsednik. Ljubljana: Modrijan, 2015.

- Ribičič, Ciril. Siva tipka 074. Ljubljana: Enotnost, 1995.

- Ritter, Gerhard A. Der Umbruch von 1989/91 und die Geschichtswissenschaft. Bayerische Akademie der Wissenschaften. Philosophisch-historische Klasse. Sitzungsberichte. Jahrgang 1995, Heft 5. München, 1995.

- Rödder, Andreas. 21.0. Eine kurze Geschichte der Gegenwart. München: C.H.Beck, 2016.

- Slovenia - 10 Years of Independence, 30 May 2016. http://www.slovenija2001.gov.si/10years/independence/.

- Suk, Jiří. "Od nezmožnosti politiky k politice jako umění možného. Paradohní život občana Václava Havla v letech 1969-1992.” In: Kapitoly z dějin české demokracie po roce 1989, eds. Adéla Gjuričová and Michal Kopeček, 16-51. Praha and Litomyšl: Paseka, 2008.

- Toš, Niko, ed. Vrednote v prehodu VIII. Slovenija v srednje in vzhodnoevropskih primerjavah 19912011. Ljubljana and Wien: Univerza v Ljubljani, Fakulteta za družbene vede, IDV-CJMMK and Edition Echoraum, 2014.

- Wintr, Jan. Česká parlamentní kultura. Praha: Auditorium, 2010.

- Wirsching, Andreas. Der Preis der Freiheit. Geschichte Europas in unserer Zeit. München: C.H.Beck, 2012.

Jure Gašparič

PISATI POLITIČNO ZGODOVINO REPUBLIKE SLOVENIJE

POVZETEK

Poskus pisanja besedila o razvoju slovenske politike v zadnjega četrt stoletja je za zgodovinarja poseben izziv in svojevrstna pustolovščina, ki že v začetku odpira nekaj važnih metodoloških vprašanj, odstira nekaj dilem, a hkrati že ponuja nekaj vnaprejšnjih odgovorov. Prvi odgovor, ki ga je pogosto zaslediti v medijih in delu strokovne javnosti, je ta, da je raziskovanje slovenske politike po letu 1991 že zanimiva in relevantna tema, a o njej ni mogoče napisati ničesar zares novega, vsaj nič takega, kar ne bi sprotni kronisti dogajanja že zapisali. Drugi vnaprejšnji odgovor, ki je pravzaprav že dilema, zadeva vprašanje obče smiselnosti raziskovanja procesov, ki še niso zaključeni. Čas naj bi bil za pogled zgodovinarja še premlad. $S$ časovno komponento je povezano naslednja dilema. Kako sploh metodološko ustrezno kot zgodovinar raziskovati nedavno politiko in fenomen političnega? Gradivo, ki je na voljo, je namreč brezbrežno v vseh ozirih - tako po količini kot po problemski in znanstveni širini.

Izzivov in dilem je nedvomno precej, vprašanje je, kako temu streči. Prva dilema, ki pravi, da ni 
mogoče o tem času napisati ničesar novega, je še najlažje obvladljiva. Pri vsakršnem resnem in metodološko osmišljenem raziskovanju namreč že teoretično ne moremo vedeti, do kakšnih interpretativnih ugotovitev bomo prišli. Ravno tako so vprašanja, ki smo si jih zastavili včeraj, morda čisto drugačna in nebistvena $\mathrm{v}$ primerjavi z vprašanji, ki nas zanimajo danes. Druga dilema, ki pravi, da je sodobni čas za zgodovinarja premlad, je do neke mere upravičena. Gotovo je enostavneje raziskovati oddaljen in zaključen proces, kakor današnji, na videz kaotičen čas. Toda prednost, ki jo predstavlja distanca, v sebi skriva nemajhno past - vedenje o koncu. Znanemu koncu (posledici) bomo iskali logične vzroke v ravnanjih ljudi in pri tem pozabili, da se $\mathrm{v}$ zgodovini stvari dogajajo tudi takrat, ko jih nihče ne načrtuje. Problematika virov je še najlažje obvladljiva. Vse vire naše dobe - tako klasične, znane že iz preteklih dob, kakor novejše (digitalne) - lahko temeljito analiziramo in pretehtamo le ob pritegnitvi dveh načinov pristopa $-\mathrm{z}$ interdisciplinarnostjo in s pomočjo orodij, ki jih danes ponuja digitalna humanistika. Raziskovanje sodobnosti se namreč bolj in bolj osredotoča na teme in probleme, pri čemer padajo meje med posameznimi disciplinami.

In kaj lahko po opravljenem raziskovanju sklepamo o politični zgodovini zadnjega četrt stoletja? Najprej se gotovo potrjuje ugotovitev, da je naša doba zelo dinamična, dogodkovno gosta in "neberlji$v a$ ". Navkljub relativni politični stabilnosti vlad je bil strankarski prostor nestabilen in spreminjajoč, v neprekinjenem prestrukturiranju. Med večjimi konstantami je bila polarizacija - delitev političnih akterjev na slovensko levico in desnico. Poleg tega lahko slovenskemu razvoju pripišemo tudi nekatere od značilnosti, ki so jih zaznali v širšem evropskem prostoru - personalizacijo politike, medializacijo in informalizacijo. Eden raziskovalnih izzivov za prihodnost je podrobno proučevanje strankarsko-politične dinamike - ne le navzven, po možnosti tudi znotraj strank, v kolikor bi bilo raziskovalcu to omogočeno. Interdisciplinarno sodelovanje pri tem ne sme izostati, saj je problematika večplastna, odgovori pa ne nujno racionalni. 